\title{
Penanganan Stroke Iskemik Akut di Masa Pandemi COVID-19
}

\author{
Erlika Lengkong, ${ }^{1}$ Finny Warouw, ${ }^{2}$ Mieke A. H. N. Kembuan ${ }^{2}$
}

\author{
${ }^{1}$ Program Studi Pendidikan Dokter Fakultas Kedokteran Universitas Sam Ratulangi, Manado, \\ Sulawesi Utara, Indonesia \\ ${ }^{2}$ Bagian Neurologi Fakultas Kedokteran Universitas Sam Ratulangi, Manado, Sulawesi Utara, \\ Indonesia \\ Email: erlikalengkong17@gmail.com
}

\begin{abstract}
When the pandemic corona virus disease (COVID-19) occurs, emergency services and hospitals are finally disrupted. One of the medical emergencies which can cause death and disability as well as other problems if being ignored, especially in productive age patients is stroke. This study was aimed to obtain the management of ischemic stroke during COVID-19 pandemic. This was a literature review study using three databases, namely Clinical Key, PubMed and Google Scholar. The keywords used in data search were acute AND stroke AND pandemic. The results showed that the treatment of acute ischemic stroke during COVID-19 pandemic consisted of three stages, namely pre-hospitalization (public education, contacting medical assistance, use of personal protective equipment, pre-notification), hospitalization (emergency room, imaging room, neuroradiology unit, ICU and IMCU), and post hospitalalization (integrated team approach). In conclusion, the management of acute ischemic stroke during COVID-19 pandemic begins before the medical personnel take action until the action is carried out. The main things in the management of acute ischemic stroke during COVID-19 pandemic are handling fast and precisely, using adequate personal protective equipment (PPE), and using communication tools or long-distance medical care (telemedicine).
\end{abstract}

Keywords: acute ischemic stroke, COVID-19, pandemic

\begin{abstract}
Abstrak: Saat terjadi pandemi corona virus disease (COVID-19), layanan kegawatdaruratan dan rumah sakit megalami perubahan. Salah satu kasus kegawatdaruratan medik yang menjadi penyebab kematian dan kecacatan serta dapat menimbulkan masalah lainnya jika diabaikan terutama pada pasien usia produktif ialah stroke. Penelitian ini bertujuan untuk mengetahui penanganan stroke pada masa pandemic COVID-19. Jenis penelitian ialah literature review yang menggunakan tiga database yaitu Clinikal key, PubMed dan Google Scholar. Kata kunci yang digunakan dalam pencarian data ialah acute AND stroke AND pandemic. Hasil penelitian mendapatkan penanganan stroke iskemik akut di masa pandemi COVID-19 terdiri dari 3 tahapan yakni prahospitalisasi (edukasi masyarakat, menghubungi bantuan medis, penggunaan alat pelindung diri, pranotifikasi rumah sakit), hospitalisasi (ruang gawat darurat, ruang pencitraan, unit neuroradiologi, ICU dan IMCU), dan pasca hospitalisasi (pendekatan tim terpadu). Simpulan penelitian ini ialah penanganan stroke iskemik akut di masa pandemi COVID-19 dimulai dari sebelum tenaga medis melakukan tindakan sampai setelah tindakan dilaksanakan. Hal utama dalam penanganan stroke iskemik akut di masa pandemi COVID-19 ialah penanganan yang cepat dan tepat, penggunaan alat pelindung diri (APD) yang memadai, dan pemanfaatan alat komunikasi atau perawatan medis jarak jauh.
\end{abstract}

Kata kunci: stroke iskemik akut, pandemi, COVID-19

\section{PENDAHULUAN}

Novel coronavirus disease (COVID-

19) telah diumumkan sebagai pandemi global oleh World Health Organization (WHO) pada tanggal 11 Maret 2020. ${ }^{1}$ Dengan adanya pandemi COVID-19 ini, 
maka fungsi dari pusat-pusat perawatan primer, layanan kegawatdaruratan, dan rumah sakit turut terpengaruh. ${ }^{2}$ Salah satu kasus kegawatdaruratan medik yang menjadi penyebab kematian dan kecacatan di dunia ialah stroke. Kerusakan neurologi yang bersifat permanen dapat terjadi jika penanganan stroke diberikan melebihi rentang waktu yang ideal. ${ }^{3}$

Berdasarkan latar belakang yang telah dipaparkan maka penulis terdorong untuk mengetahui secara detil mengenai penanganan pasien dengan stroke iskemik akut di masa pandemik COVID-19 mengingat di satu sisi pasien tersebut memerlukan penanganan sedini mungkin, namun tetap harus mengikuti prosedur sesuai dengan ketentuan protokol COVID-19.

\section{METODE PENELITIAN}

Penelitian ini berbentuk suatu literature review. Pencarian data literatur menggunakan tiga database yaitu ClinicalKey, Pub Med dan Google Scholar dengan memasukkan tiga kata kunci yakni acute AND stroke AND pandemic. Setelah ditemukan sejumlah besar literatur, maka dilakukan evaluasi data untuk menentukan literatur yang memberi kontribusi dalam memahami topik dengan menggunakan kriteria inklusi dan esklusi PICOS framework ditambah dengan kriteria tahun dan bahasa yang digunakan. Analisis dan Interpretasi data dengan cara membahas temuan dan simpulan yang paling berhubungan dari literatur tersebut melalui tahapan seleksi studi.

\section{HASIL PENELITIAN}

Pada tahapan seleksi literatur diperoleh sebanyak 411 literatur menggunakan ClinicalKey, 535 literatur menggunakan Pub Med, 413 literatur menggunakan Google Scholar $(\mathrm{n}=1.359)$ yang sesuai. Hasil pencarian yang telah diperoleh kemudian dilakukan skrining berdasarkan judul yang sesuai dengan tema penelitian ini dan diperoleh 30 artikel $(n=30)$. Selanjutnya 30 artikel tersebut dilakukan skrining fulltext sesuai kriteria dan didapatkan 10 artikel yang akan dikaji $(\mathrm{n}=10)$.

Hasil seleksi literatur mendapatkan 10 literatur yang memenuhi kriteria inklusi dan ekslusi (Tabel 1). Secara keseluruhan, kesepuluh literatur tersebut terbagi menjadi tiga tahap dalam penanganan stroke yakni tahap prahospitalisasi, tahap hospitalisasi dan tahap pasca hospitalisasi .

Tabel 2 memperlihatkan hasil kajian dari 10 literatur yang digunakan dalam penelitian ini sesuai dengan tahap penangan pasien dengan stroke iskemik di masa pandemi COVID-19.

Tabel 1. Kriteria inklusi dan ekslusi dalam penelitian

\begin{tabular}{|c|c|c|}
\hline Kriteria & Inklusi & Eksklusi \\
\hline Population/Problem & $\begin{array}{l}\text { Penanganan Stroke Iskemik } \\
\text { Akut }\end{array}$ & $\begin{array}{l}\text { Tidak di masa pandemi } \\
\text { COVID-19, } \\
\text { rehabilitasi }\end{array}$ \\
\hline Intervention & - & - \\
\hline Comparation & - & - \\
\hline Outcome & - & - \\
\hline Study design & $\begin{array}{l}\text { Guideline, } \\
\text { Deskriptif }\end{array}$ & Tidak tersedia fulltext \\
\hline Tahun & $2019-2020$ & \\
\hline Bahasa & Inggris, Indonesia & \\
\hline
\end{tabular}

Tabel 2. Tahapan prahospitalisasi, hospitalisasi, paska hospitalisasi masing-masing literatur

\begin{tabular}{|c|c|c|c|c|c|}
\hline No & Penulis & Judul & Prahospitalisasi & Hospitalisasi & $\begin{array}{c}\text { Pasca } \\
\text { hospitalisasi }\end{array}$ \\
\hline 1 & De Silva et $\mathrm{al}^{4}$ & $\begin{array}{l}\text { A protocol for acute } \\
\text { stroke unit care } \\
\text { during the COVID-19 } \\
\text { pandemic. }\end{array}$ & $\begin{array}{l}\text { Tidak dibahas khu- } \\
\text { sus }\end{array}$ & $\begin{array}{l}\text { Melaksanakan peman- } \\
\text { tauan akut yakni obser- } \\
\text { vasi masalah neuro- } \\
\text { logis, pengukuran te- }\end{array}$ & $\begin{array}{l}\text { Unified team } \\
\text { approach (Pende- } \\
\text { katan Tim Terpa- } \\
\text { du) berupa peme- }\end{array}$ \\
\hline
\end{tabular}


2 Dafer et $\mathrm{al}^{5}$

3

Co et $\mathrm{al}^{6}$

Qureshi et $\mathrm{al}^{7}$
Acute stroke care in the coronavirus disease 2019 pandemic.

Acute stroke care algorithm in a private tertiary hospital in the Philippines during the COVID-19 pandemic: A third world country experience.

Management of acute ischemic stroke in patients with COVID19 infection: Insights from an international panel.

Al Hashmi et al ${ }^{8} \quad$ Current recommenddations for the management of stroke patients in the Middle East in the era of COVID-19

pandemic; Statement from the MENA SINO.

kanan darah, pembuatan grafik input-output, investigasi dan masalah khusus setelah perawatan reperfusi hiperakut. Kemudian mengidentifikasi dan menangani segera komplikasi stroke se perti tromboemboli vena, komplikasi dis fagia termasuk pneumo nia aspirasi, kompli kasi dari tuba dan saluran, komplikasi imobilitas dan masalah nutrisi.

Menghubungi petugas medis gawat darurat ketika terjadi serangan stroke, melakukan skrining COVID-19 dan penapisan keparahan stroke.

Menerapkan penggunaan APD dan melakukan skrining COVID-19

Mengarahkan bahwa jumlah minimal tenaga medis profesional hadir dan tenaga medis yang berisiko tinggi terinfeksi tidak ikut melakukan evaluasi.

Menerapkan penggunaan APD, prosedur triase dan pranotifikasi stroke ke rumah sakit.

riksaan harian pada tim stroke, edukasi pasien, komunikasi dengan keluarga, perencanaan pulang dan dukungan setelah pulang.

Melaksanakan evaluasi di Ruang Gawat Darurat berupa skrining COVID-19, evaluasi untuk trombolisis dengan aktivator plasminogen jaringan intravena (rTPA) dan trombektomi endovaskular dan pembagian masker bedah. Selanjutnya pemantauan terhadap pasien trombolisis intravena dan penempatan pasien paska trombolisis.

Pelaksanaan prosedur Tidak dibahas skrining COVID-19, khusus. pembagian pasien brain attack (BAT) atau bukan BAT, pembagian masker, prosedur IV rTPA, prosedur trombektomi endovaskular, layanan bedah saraf untuk kasus perdarahan.

Mengidentifikasi

Tidak dibahas pasien yang akan menjalani trombektomi mekanis

khusus.

Pengaturan di emer- Follow up pasien gency room, CT room, angiography suite, stroke unit.

Tidak dibahas khusus. 


\begin{tabular}{|c|c|c|c|c|c|c|}
\hline 6 & Goyal et $\mathrm{al}^{9}$ & $\begin{array}{l}\text { Prehospital triage of } \\
\text { acute stroke patients } \\
\text { during the COVID-19 } \\
\text { pandemic. }\end{array}$ & $\begin{array}{l}\text { Menerapkan prose- } \\
\text { dur triase, skrining } \\
\text { COVID-19 online, } \\
\text { pranotifikasi rumah } \\
\text { sakit dan telestroke. }\end{array}$ & $\begin{array}{l}\text { Mengonfirmasi } \\
\text { kembali status } \\
\text { COVID-19 pada petu- } \\
\text { gas gawat darurat yang } \\
\text { membawa pasien. Jika } \\
\text { pasien terduga atau } \\
\text { terkonfirmasi positif } \\
\text { COVID-19 maka mo- } \\
\text { nitoring dari saturasi } \\
\text { oksigen, tekanan da- } \\
\text { rah, laju nadi dan laju } \\
\text { pernapasan } \\
\text { dilanjutkan. }\end{array}$ & $\begin{array}{l}\text { Tidak } \\
\text { khusus. }\end{array}$ & dibahas \\
\hline 7 & $\begin{array}{l}\text { Baracchini et } \\
\mathrm{al}^{10}\end{array}$ & $\begin{array}{l}\text { Acute stroke manage- } \\
\text { ment pathway during } \\
\text { coronavirus-19 } \\
\text { pandemic. }\end{array}$ & $\begin{array}{l}\text { Tidak dibahas } \\
\text { khusus. }\end{array}$ & $\begin{array}{l}\text { Melakukan skrining } \\
\text { COVID-19, pemerik- } \\
\text { saan neuroimaging, } \\
\text { protokol trombolisis } \\
\text { intravena, penempatan } \\
\text { pasien di bangsal } \\
\text { medis khusus penyakit } \\
\text { menular jika stroke } \\
\text { iskemiknya tidak ter- } \\
\text { jadi karena oklusi } \\
\text { pembuluh darah besar } \\
\text { dan unit neuroradiologi } \\
\text { jika karena oklusi pem- } \\
\text { buluh darah besar un- } \\
\text { tuk mendapatkan pera- } \\
\text { watan endovaskular. }\end{array}$ & $\begin{array}{l}\text { Tidak } \\
\text { khusus. }\end{array}$ & dibahas \\
\hline 8 & Zaidi et al $^{11}$ & $\begin{array}{l}\text { Malaysia stroke } \\
\text { council guide on } \\
\text { acute stroke care } \\
\text { service during } \\
\text { COVID-19 pandemic. }\end{array}$ & $\begin{array}{l}\text { Mengedukasi ma- } \\
\text { syarakat tentang } \\
\text { penanganan stroke } \\
\text { akut dimasa pande- } \\
\text { mi COVID-19 dan } \\
\text { penggunaan APD } \\
\text { yang memadai. }\end{array}$ & $\begin{array}{l}\text { Melakukan peme- } \\
\text { riksaan neuroimaging, } \\
\text { melakukan prosedur } \\
\text { intravenous thrombo- } \\
\text { lysis (IVT) dengan } \\
\text { Alteplase (bagi yang } \\
\text { memenuhi syarat), pro- } \\
\text { sedur trombektomi } \\
\text { endovaskular. }\end{array}$ & $\begin{array}{l}\text { Tidak } \\
\text { khusus. }\end{array}$ & dibahas \\
\hline 9 & Bhaskar et al $^{12}$ & $\begin{array}{l}\text { Acute neurological } \\
\text { care in the COVID-19 } \\
\text { Era: The Pandemic } \\
\text { Health System } \\
\text { REsilience } \\
\text { PROGRAM } \\
\text { (REPROGRAM) } \\
\text { Consortium Pathway. }\end{array}$ & $\begin{array}{l}\text { Penerapan prosedur } \\
\text { skrining COVID-19 } \\
\text { dengan PCR dan } \\
\text { Penggunaan APD } \\
\text { yang memadai dis } \\
\text { emua tahapan pera- } \\
\text { watan. }\end{array}$ & $\begin{array}{l}\text { Pemisahan perawatan } \\
\text { antara pasien COVID- } \\
19 \text { dan bukan COVID- } \\
19 .\end{array}$ & $\begin{array}{l}\text { Tidak } \\
\text { khusus. }\end{array}$ & dibahas \\
\hline 10 & $\begin{array}{l}\text { Khosravani et } \\
\mathrm{al}^{13}\end{array}$ & $\begin{array}{l}\text { Protected code } \\
\text { stroke: hyperacute } \\
\text { stroke management } \\
\text { during the Corona- } \\
\text { virus Disease } 2019 \\
\text { (COVID-19) } \\
\text { Pandemic. }\end{array}$ & $\begin{array}{lr}\text { Penerapan prosedur } \\
\text { skrining infeksi } \\
\text { COVID-19 } \\
\text { Protected } & \text { Code } \\
\text { Stroke (PCS) } & \end{array}$ & $\begin{array}{l}\text { Pengaktifan protected } \\
\text { code stroke (PCS). }\end{array}$ & $\begin{array}{l}\text { Tidak } \\
\text { khusus. }\end{array}$ & dibahas \\
\hline
\end{tabular}

\section{BAHASAN}

Hasil kajian penelitian ini mendapatkan bahwa penanganan stroke iskemik akut dibagi dalam beberapa variasi tahapan demi mencapai penanganan yang adekuat, lalu dirangkum dan dibahas dengan menggabungkannya bersama alur teknik pelayanan rumah sakit di masa COVID-19 yang ada di Indonesia. ${ }^{14}$

Tahapan pertama ialah pra-hospita- 
lisasi. Tahapan ini didahului dengan edukasi publik. Banyaknya pasien COVID-19 yang dibawa ke rumah sakit membuat sebagian dari masyarakat enggan untuk pergi ke rumah sakit atau fasilitas kesehatan meskipun dalam keadaan darurat atau berhadapan dengan kondisi gawat darurat seperti stroke yang dialami oleh orang di sekitarnya. Oleh karena itu, penting untuk mengedukasi masyarakat bahwa stroke maupun kondisi gawat darurat lain perlu mendapatkan penanganan walaupun di masa pandemi COVID-19 ini. ${ }^{11}$ Pasien yang mengalami serangan atau kecurigaan stroke harus segera menghubungi petugas emergency medical system (EMS). Petugas EMS melakukan skrining COVID-19 pada pasien melalui telepon tidak lama setelah mendapat panggilan dari pasien jika memungkinkan. Pasien dengan kecurigaan stroke yang rendah atau dengan gejala minimal yang tidak memerlukan intervensi segera dapat melakukan telemedicine dengan petugas medis untuk ditentukan apakah memerlukan perawatan di rumah sakit dengan segera. ${ }^{5}$ Petugas medis harus sudah menggunakan APD ketika tiba di lokasi kejadian dan melakukan skrining COVID-19 pada pasien secara online jika langkah sebelumnya yakni skrining melalui telepon sulit dilakukan. Ketika pasien harus segera dibawa ke rumah sakit maka petugas EMS harus memberitahukan terlebih dahulu rumah sakit yang dituju tentang kondisi pasien termasuk status COVID-19 yang dimiliki pasien agar rumah sakit sudah siap terlebih dahulu sebelum pasien datang. ${ }^{5,8,9}$ Proses pengangkutan pasien stroke juga harus segera dengan mengikuti onset-todoor time $\leq 3 \mathrm{jam}$, door-to-imaging time $\leq 25$ menit, dan door-to-needle time $\leq 60$ menit. ${ }^{15}$

Tahapan kedua ialah tahap hospitalisasi. Pasien yang tiba di instalasi gawat darurat (IGD) seharusnya melakukan skrining COVID-19, namun pasien bisa tidak perlu dilakukan skrining dan langsung diarahkan ke triase COVID-19 jika sudah suspek atau terkonfirmasi COVID-19 ketika dirujuk atau dibawa oleh ambulans. Apabila rujukan kasus tersebut ialah non COVID-19 namun gawat darurat maka pasien dapat juga tidak dilakukan skrining jika tidak memungkinkan dengan syarat untuk memperlakukan pasien tersebut sebagai kelompok pasien suspek atau terkonfirmasi COVID-19 sampai terbukti tidak. ${ }^{14}$ Sebelum dilakukannya transfer pasien, harus dipastikan catatan skrining COVID-19 beserta riwayat perjalanan pada pasien sudah diterima atau dilengkapi oleh petugas kesehatan di rumah sakit. Jika riwayat perjalanan atau riwayat epidemiologi positif maka protected code stroke diaktifkan. ${ }^{13}$ Setelah itu pasien diobservasi menegnai masalah neurologiknya dengan menggunakan Glasgow Coma Scale (GCS), pemeriksaan ukuran dan reaksi pupil, serta beberapa komponen dari National Institute Health Stroke Scale (NIHSS) yakni komponen 1, 10, 5 dan 6 (tingkat kesadaran, disatria, motorik lengan dan motorik kaki). ${ }^{4}$ Jikalau saat penentuan riwayat perjalanan pasien sulit diketahui karena pasien kurang kooperatif dan/atau tidak adanya saudara atau kerabat, maka protected code stroke dapat diaktifkan ketika terjadi penurunan kesadaran. ${ }^{13}$

Pemantauan akut lainnya ialah dengan melakukan pengukuran tekanan darah dengan perlu menentukan target spesifik untuk pasien serta membuat grafik inputoutput pasien setiap hari. ${ }^{4}$ Selain tekanan darah, pasien dengan dugaan atau terkonfirmasi COVID-19 akan dimonitor saturasi oksigennya serta laju nadi dan laju pernapasan pasien. ${ }^{9}$ Pasien kemudian dilakukan evaluasi untuk potensi trombolisis dengan aktivator plasminogen jaringan intravena (rTPA). ${ }^{5}$ Bagi pasien yang memenuhi syarat akan dilakukan tindakan intravenous thrombolysis (IVT) dengan Alteplase sebagai perawatan standar. ${ }^{11}$ Pemantauan pada pasien yang menerima trombolisis kimiawi intravena dapat dilakukan secara virtual melalui konferensi video dua arah untuk menghindari paparan yang tidak perlu dari petugas. ${ }^{5}$ Selain itu perlu diwaspadai adanya komplikasi stroke yang dapat terjadi seperti tromboemboli vena, komplikasi disfagia termasuk pneumonia aspirasi, komplikasi dari tuba dan saluran, komplikasi imobilitas, dan masalah nutrisi 
yang perlu dideteksi segera untuk pencegahan atau agar mendapatkan penanganan segera jika ada. ${ }^{4}$ Bagi pasien yang membutuhkan intervensi bedah dirujuk ke layanan bedah saraf. $^{6}$

Penentuan risiko COVID-19 dapat dilakukan dengan memperhatikan status klinis pasien, radiografi dada, dan parameter laboratorium sambil menunggu konfirmasi hasil usap nasofaring. ${ }^{6}$ Dengan demikian semua pasien harus diperlakukan sebagai pasien yang terkonfirmasi positif COVID19 sampai hasil tes keluar. ${ }^{12}$

Pada pengaturan di CT room usahakan agar ruang CT scan pasien COVID-19 dan bukan COVID-19 dibuat terpisah. ${ }^{8}$ Identifikasi pasien untuk trombektomi dapat berupa evaluasi secara klinis dan CT scan berbasis kontras seperti CT angiography (CTA) dan CT perfusion (CTP) dengan melakukan evaluasi ginjal terhadap penggunaan kontras terlebih dahulu. ${ }^{7}$ Namun pasien akan menunggu hasil skrining COVID-19 dengan dipantau oleh tim stroke di area khusus jika tidak ada indikasi untuk trombektomi. ${ }^{10}$ Dalam ruangan ini juga sebaiknya dibatasi jumlah kunjungan untuk meminimalkan risiko penularan dan mencegah pemborosan APD. ${ }^{8}$ Apabila stroke iskemik disebabkan oleh oklusi pembuluh darah besar maka pasien akan melakukan pengobatan endovaskular di Unit Neuroradiologi dengan memperingatkan agar para petugas yang menanganinya menggunakan APD yang memadai. ${ }^{10}$ Trombektomi endovaskular sebaiknya dilakukan dengan sedasi sadar. ${ }^{11}$ Pasien stroke paska trombolisis dapat dirawat di IMCU jika memungkinkan dengan pengawasan ahli saraf, sedangkan ruang ICU ditempatkan oleh pasien stroke yang berat dan membutuhkan perawatan intensif atau dalam kondisi kritis dengan pengawasan dokter intensivist ketika rumah sakit sedang ramai dengan pasien COVID19. ${ }^{5}$ Pasien akan dipindahkan ke Unit Stroke atau Neuro-ICU jika hasil skrining COVID19 negatif, sedangkan pasien akan dipindahkan ke bangsal unit khusus penyakit infeksi dengan dipantau oleh tim stroke dan internis jika hasil skrining pasien positif COVID$19 .^{10}$
Tahapan ketiga ialah pasca hospitallisasi. Tahap tiga ini bertujuan untuk mengadakan sebuah program yang dapat membahas tentang pemeriksaan harian pada tim stroke, edukasi pasien dan keluarga, perencanaan pulang dan dukungan setelah pulang, termasuk didalamnya follow up pasien yang dapat dilakukan melalui konsultasi melalui telestroke. ${ }^{4,8}$

\section{SIMPULAN}

Penanganan stroke iskemik akut di masa pandemi COVID-19 dimulai dari sebelum tenaga medis melakukan tindakan sampai setelah tindakan dilaksanakan, yang memerlukan penanganan cepat dan tepat, penggunaan alat pelindung diri (APD) yang memadai, dan pemanfaatan alat komunikasi atau perawatan medis jarak jauh (telemedicine) demi pelayanan dengan risiko infeksi minimal.

\section{DAFTAR PUSTAKA}

1. Cucinotta D, Vanelli M. WHO declares COVID-19 a pandemic. Acta Biomed. 2020;91(1):157-60.

2. Rodríguez-Pardo J, Fuentes B, de Leciñana AM, Campollo J, Castaño PC, Ruiz JC, et al. Acute stroke care during the COVID-19 pandemic. Ictus Madrid Program recommendations. Neurol (English Ed). 2020;35(4):258-63.

3. Arif M, Okraini N, Putra AYM. Hubungan ketepatan "golden period" dengan derajat kerusakan neurologi pada pasien stroke iskemik di ruang Instalasi Gawat Darurat Rumah Sakit Stroke Nasional Bukittinggi. Prosiding Seminar Kesehatan Perintis. 2018;1(1):1-8.

4. De Silva DA, Tan IF, Thilarajah S. A protocol for acute stroke unit care during the COVID-19 pandemic. J Stroke Cerebrovasc Dis. 2020;29(9):105009.

5. Dafer RM, Osteraas ND, Biller J. Acute stroke care in the coronavirus disease 2019 pandemic. J Stroke Cerebrovasc Dis. 2020;29(7):104881.

6. Co COC, Yu JRT, Macrohon-Valdez MC, Laxamana LC, De Guzman VPE, Remy Margarette M, et al. Acute stroke care algorithm in a private tertiary hospital in the Philippines during the COVID-19 pandemic: a third world country 
experience. J Stroke Cerebrovasc Dis. 2020;29(9):105059.

7. Qureshi AI, Abd-Allah F, Al-Senani F, Aytac E, Borhani-Haghighi A, Ciccone A, et al. Management of acute ischemic stroke in patients with COVID-19 infection: Insights from an international panel. Am J Emerg Med. 2020;38(7): 1548.e5-1548.e7.

8. Al Hashmi AM, Ozdemir AO, Shuaib A, AlJehani H, Mansour OY, Alhazzani A et al. Current Recommendations for the Management of Stroke Patients in the Middle East in the Era of COVID-19 Pandemic; Statement from the MENA SINO. J Stroke Cerebrovasc Dis. 2020;29(11):105181.

9. Goyal M, Ospel JM, Southerland AM, Wira C, Amin-Hanjani S, Fraser JF et al. Prehospital triage of acute stroke patients during the COVID-19 pandemic. Stroke. 2020;(July):2263-7.

10. Baracchini C, Pieroni A, Viaro F, Cianci V, Cattelan AM, Tiberio I, et al. Acute stroke management pathway during Coronavirus-19 pandemic. Neurol Sci. 2020;41(5):1003-5.

11. Zaidi WAW, Khan AHKY, Chung LW, Kee HF, Looi I, Lip AC, et al. Malaysia stroke council guide on acute stroke care service during COVID-19 pandemic. Med J Malaysia. 2020;75(3):311-313.

12. Bhaskar S, Sharma D, Walker AH, McDonald M, Huasen B, Haridas A, et al. Acute neurological care in the covid-19 era: The Pandemic Health System REsilience PROGRAM (REPROGRAM) Consortium Pathway. Front Neurol. 2020;11(May):1-8.

13. Khosravani $H$, Rajendram $P$, Notario $L$, Chapman MG, Menon BK. Protected Code Stroke: Hyperacute stroke management during the coronavirus Disease 2019 (COVID-19) pandemic. Stroke. 2020;2019:1891-5.

14. Kemkes. Panduan Teknis Pelayanan Rumah Sakit, 2020. Available from: https:// covid19.go.id/p/protokol/panduanteknis-pelayanan-rumah-sakit-padamasa-adaptasi-kebiasaan-baru

15. Powers WJ, Rabinstein AA, Ackerson T, Adeoye OM, Bambakidis NC, Becker K, et al. 2018 Guidelines for the early management of patients with acute ischemic stroke: a guideline for healthcare professionals from the American Heart Association/American Stroke Association. Stroke. 2018;49(3):e46-e49. 